\title{
Integrating webistes to self access language learning: a strategic way to facilitate the autonomous learning
}

\author{
Supardi \\ University of Jember, Indonesia \\ supardi@unej.ac.id
}

\begin{abstract}
Up to this present time, self acccess language learning (SALL) has become an interesting topic for study. Many scholars have devoted their attention to the study on this topic that many of their papers are published in Studies in Self-Access Learning journal. Though many studies have discussed this topic, the websites that can be integrated into SALL as a strategic way to facilitate the autonomous learning remains underresearched. This paper is based on a research looking at the integration of websites into SALL from the perspective of SALL materials in an online SALL centre. It looks at which English language skills are offered as SALL materials and which websites provide SALL materials. The data concerning these two themes were collected from the online visit to Self Access Centre and Independent Learning (SACIL) set up at the University of Waikato. SALL materials in SACIL include general language skills, grammar, reading, listening, speaking and pronunciation, writing, punctuation, voacabulary and spelling, IELTS, and study skills and exam preparation which are linked to a large number of websites. With these website-based SALL materials the learners all over the world can finally practice their English skills autonomously.
\end{abstract}

Key words: website, self-access language learning, autonomous learning

\section{Introduction}

Self-access learning plays an important role in language education in many parts of the world (Gardner and Miller, 2011). In this role it was firstly established in CRAPEL (Centre de Recherches et d'Applications Pdagogiques en Langues) at the University of Nancy, France (Gremmo and Riley, 1995). Since then, it has been developed in such locations as the United States, throughout Europe, Asia, and elsewhere around the globe (McMurry, Tanner, Anderson, 2010). As a consequence, SALL has finally become an interesting topic for study by many scholars up to the present time.

In Studies in Self-Access Learning (SISAL) journal, for example, the article Autonomous Language Learning in Self-Access Spaces Moodle in Action discusses that the concept of autonomous language learning (ALL) opportunities using moodle can be woven into practice (Dofs, K., and Hobbs, M., 2016). In addition, in the article Accessibility and the Promotion of Autonomous EFL Reading, Cheetham, C., Elliott, M., Harper, A., and Ito, M., (2017) state that the main library plays an important role in the ER program by making students responsible for their own learning and initiative, but the mobile library proves to be more successful at getting students to engage in ER and develop autonomous reading skills. As well as these two articles, there are also many others that can be accessed from SISAL journal or orher journals relating English language teachhing and learning.

Although many scholars have devoted their attention to the study on SALL, the two papers above and the others published in SISAL journal or others can certainly lead the other schoolars to conduct many further studies on the same topic but in different object, because SALL has become the interesting topic for study up to the present time. For these reasons, this current study focuses its discussion on the basis of a reasearch looking at the integration of website into SALL from the perspective of SALL materials which are provided in Self Access Centre and Independent Learning (SACIL) established at the University of Waikato. With this focus, the study finally aims at exploring and describing which English language skills as SALL materials are offered at SACIL and which websites are linked to the SALL materials offered at SACIL.

\section{Literaturre Review Websites}

It is the fact that website has its vital role in English language teaching and learning (ELTL). For this fact, Kir and Kayak (2013) argue that the role of websites in learning foreign languages has been progressively increasing due to the educational technology development. As a result, in this era of 
digital technology like nowadays, the emergence of website in ELTL cannot be avoided by the teachers of both English as a Foreign Language (EFL) and English as a Second Language (ESL). In other words, the teachers of EFL and ESL have to consider it as an important thing that they cannot ignore in their teaching activities. Concerning this importance ofwebsite in ELTL, Murray and McPherson (2004) point out that many ESL websites offer teaching materials, lessons plans, games and other instructional resources that are freely available to students and teachers.

As website is important in ELTL because of the development in educational technology, it certainly has many benefits in ELTL. According to Motteram (2013), the digital technologies give benefits to both teachers that they can work with the learners and the learners that they can work independently and make their language possible. In the words of Lynch and Campos (2014) using technology development in the language class has at least such advantages as making the learner more interested about the subject, decreasing learning time, and providing opportunities to learn in non-traditional ways. Paying attention to these benefits/advantages of website in ELTL due to the educational technology development, it is therefore appropriately necessary to integrate website into SALL.

\section{Self-access language learning (SALL)}

To discuss SALL in this paper, it is firstly important to understand what the term self-access means. This term is defined as in the following definition.

Self-access is a way of describing learning materials that are designed and organised in such a way that students can select and work on tasks on their own (although this does not preclude the possibility of various kinds of support), and obtain feedback on their performance, for example by comparing their answers to a key which accompanies the material (Sheerin, 1991 cited in Slavia, 2000).

According to this definition, learning materials designed and organised in such a way are certainly very important in setting up SALL. As a result, the learners in SALL have their own responsibilty to select the designed and organised learning materials and work on their own. In addition, in SALL they can obtain feed back on their performance by comparing their answers attached to the materials. From this point, SALL is based on the learner-centred approach, which supports learning based on students active rather than passive participation (Gibbs, 1995 cited in Papadima-Sophocleous, 2013), on student (rather than teacher) responsibility for learning and on autonomous learning. SALL is most frequently established in SALL institution or Self Access Centre, such as SACIL set up at the University of Waikato.

\section{Autonomous learning}

Scholars have defined autonomous learning in different ways. On the one hand, it means the ability of the learners to take charge of their own learning (Holec, 1981). In addition, it is a capacity-for detachment, critical reflection, decision-making and independent action (Littlewood,1991). On the other hand, it is defined as the capacity to take control of ones own learning (Benson, 2001). Although autonomous learning is differently defined, it leads into an understanding that the autonomous learners are those who have capacity to be responsible for taking charge of, detachment, critical reflection, decision-making, independent action, and taking control of their won learning. For this undertstanding, it is necessary for the teachers to think of how to ficilitate the autonomous learning strategically.

To answer this question, it is necessary to pay attetion to the emergence of websites provided by the Internet. In the digital era like nowadays, the websites have contributed their advantages to ELTL (see Lynch and Campos, 2014, Motteram, 2013, and Murray and McPherson, 2004) such as offering materials, making the learners more interested about the subject, decreasing learning time, and providing opportunities to learn in non-traditional ways. Paying attention to these benefits of websites in ELTL, it is therefore important to integrate the websites into SALL as a strategical way to facilitate the autonmous learning.

\section{Method}

This paper is based on research looking at the integration of websites into SALL from the perspective of SALL materials in an online SALL at SACIL established at the University of Waikato. It focuses on exploring and describing the integration of websites into SALL as a strategic way to facilitate the autonomous learning at SACIL. For this focus, the two research questions are formulated as in the followings.

RQ-1: Which English language skills as SALL materials are offered at SACIL?

RQ-2: Which websites are linked to SALL materials at SACIL? 
In order to get the answers of the research questions above, the data concerning the two research questions were collected from the online visit to SACIL set up at the University of Waikato. The collected data were then presented into figures that ca be seen in the section below.

\section{Result and Discussion}

Self Access Center and Independent Learning at the University of Waikato

A main purpose of SALL establishment is the fostering of autonomous learning (Fisher et al., 2007; Gardner and Miller, 1997, 1999; Morrison, 2008; Sheerin, 1989 cited in Gardner and Miller, 2011). Regarding this purpose, Self Access Centre and Independent Learning (SACIL) set up under English Language Resource Centre at the Unversity of
Waikato is to foster the autonomous learning of the students of the Unversity of Waikato. With this kind of learning mode, SACIL aims at improving language learning and research skills for further tertiary study, as well as to help with life in New Zealand.

In order the students can improve their English skills through the autonomous learning, SACIL offers both offline and online SALL materials. In term of offline materials, there is an extensive collection of language books with answer keys, audio, and reference. In addition, in term of online SALL materials, in SACIL the students can practice their English language skills from SALL materials mentioned in the figure below.

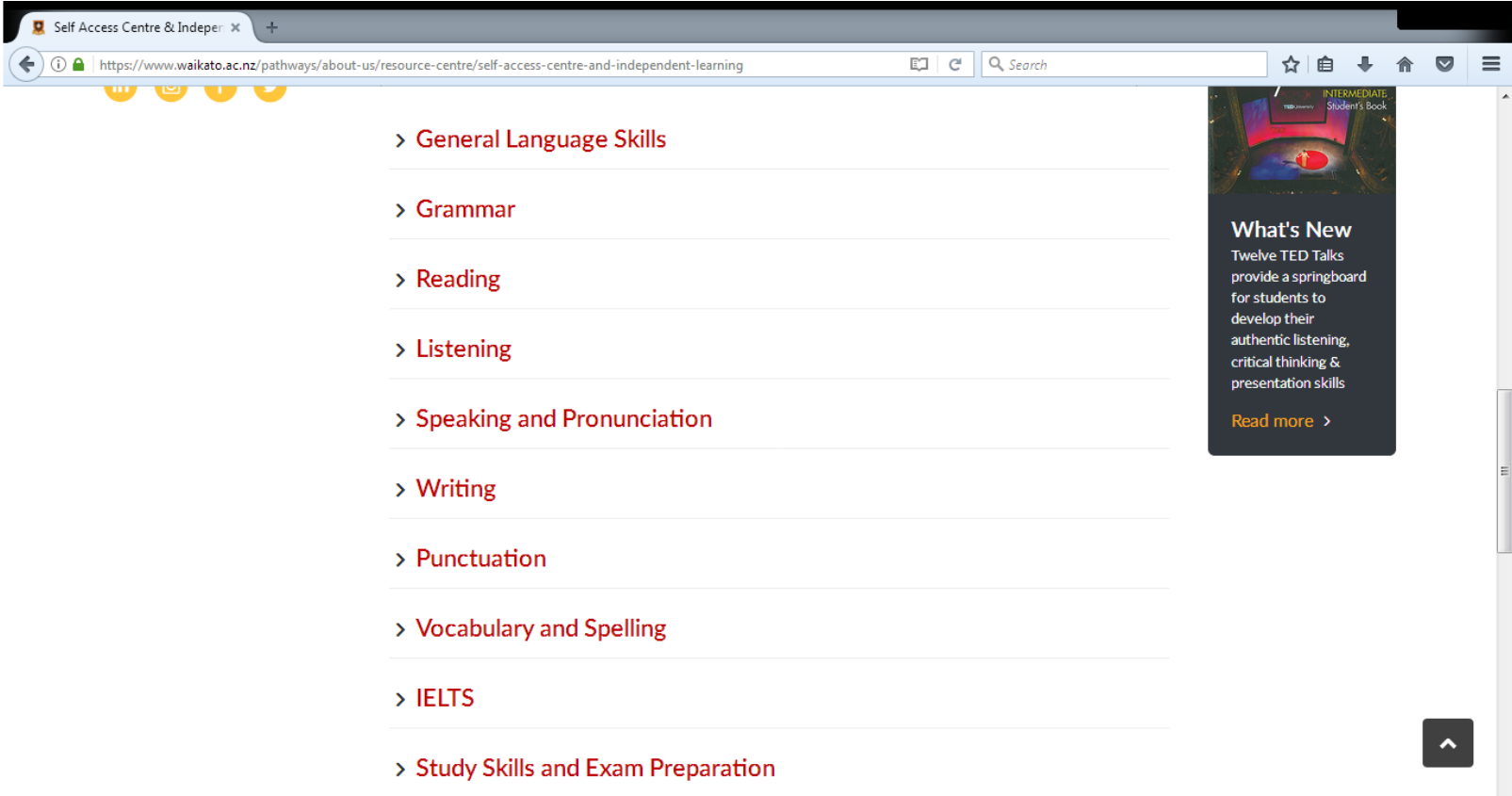

Figure 1. Online SALL Materials at SACIL

The figure above shows that there are ten core subjects for online SALL materials at SACIL. They include General Language Skills, Grammar, Reading, Listening, Speaking and Pronunciation, Writing, Punctuation, Vocabulary and Spelling, IELTS, and Study Skills and Exam Preparation. Not only the students of the University of Waikato can learn those materials, but other learners over the world can also access each of such English language skills online either inside or outside the SACIL room because those materials are linked to a large number of websites. From these SALL materials, the learners can select one of them they need. Using their personal computers, laptops, or smartphones they can then access those materials anywehere, anytime they like. When they click each of them, such materials and websites will appear as in the follwing figures. 
Leksika Vol.13 No.1 - Feb 2019: 1 - 11

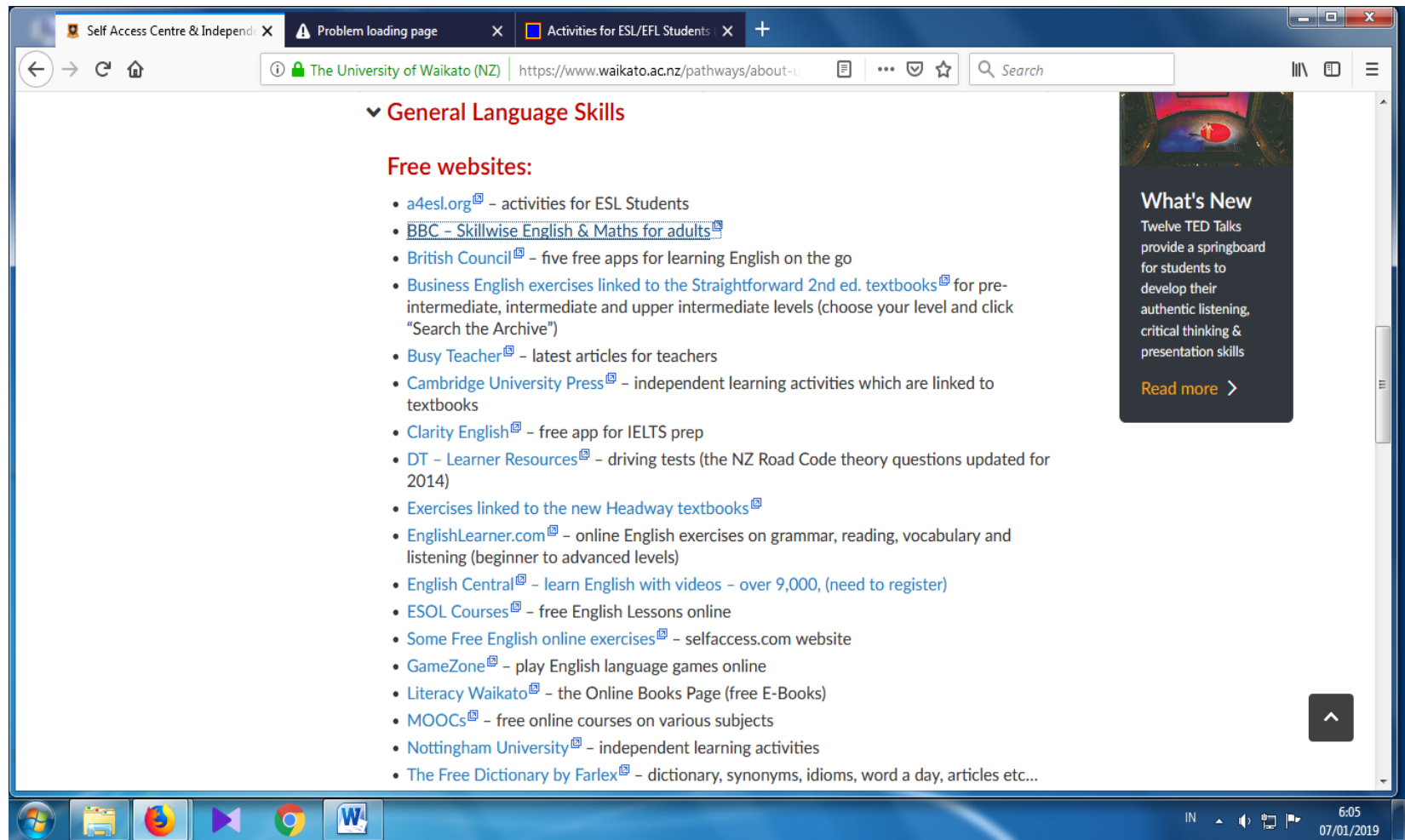

Figure 2. General Language Skills

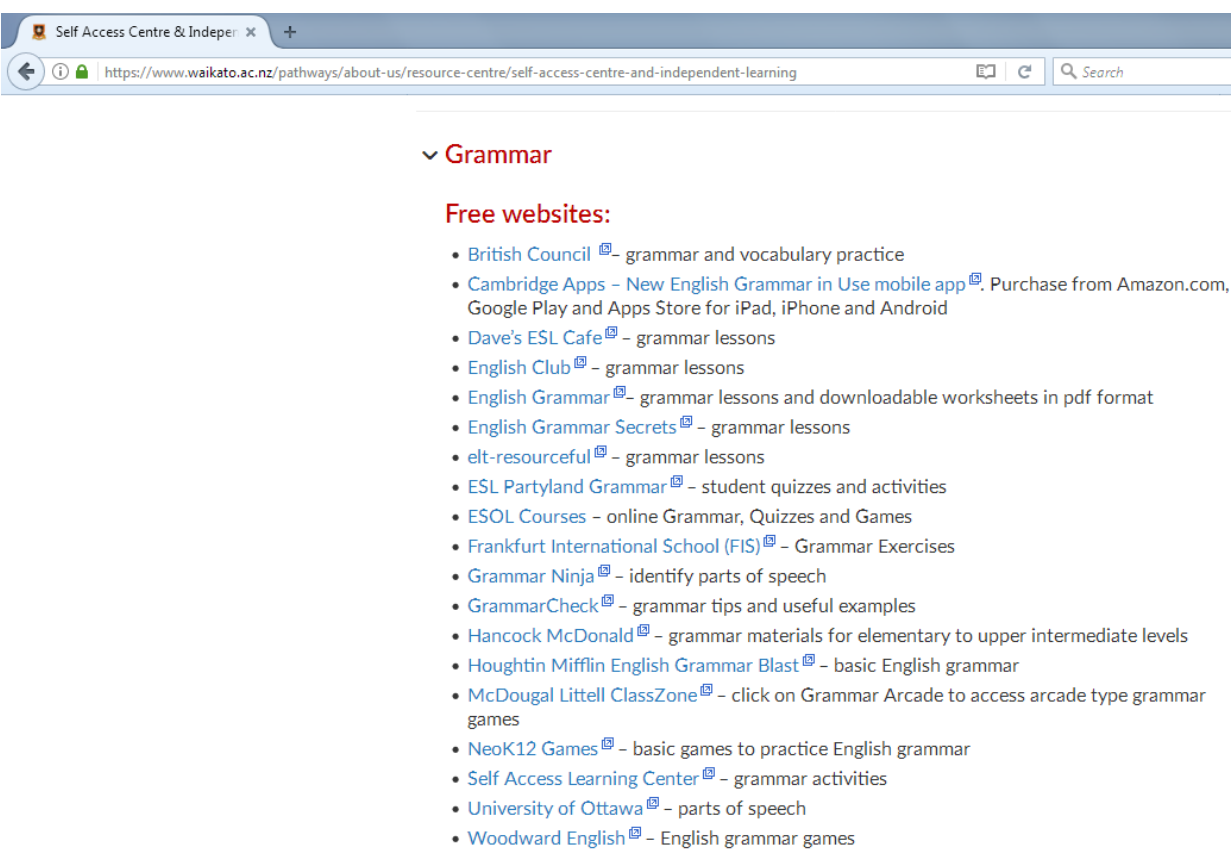

(2) F 9 (3)

Figure 3. Grammar 


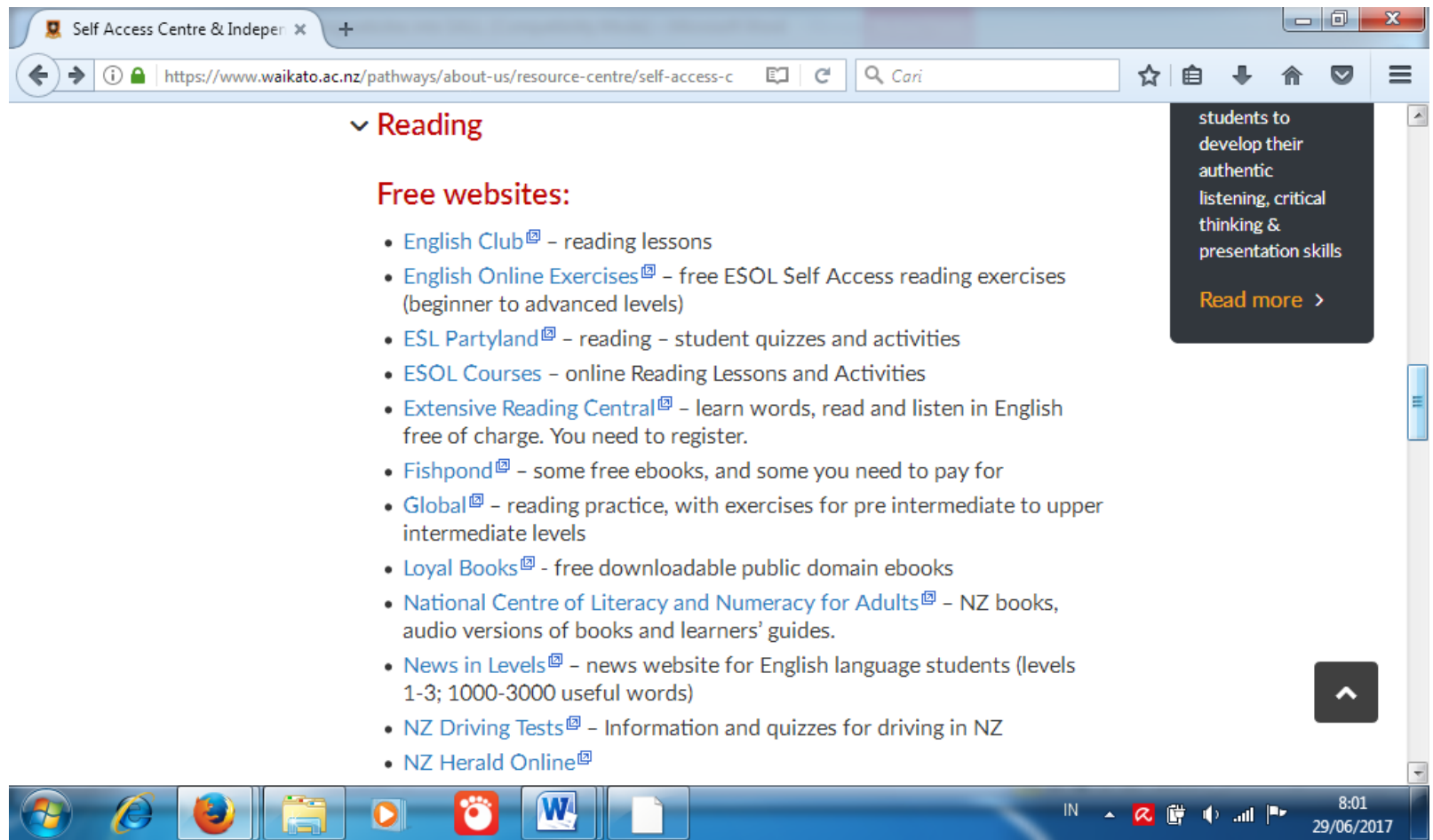

Figure 4. Reading

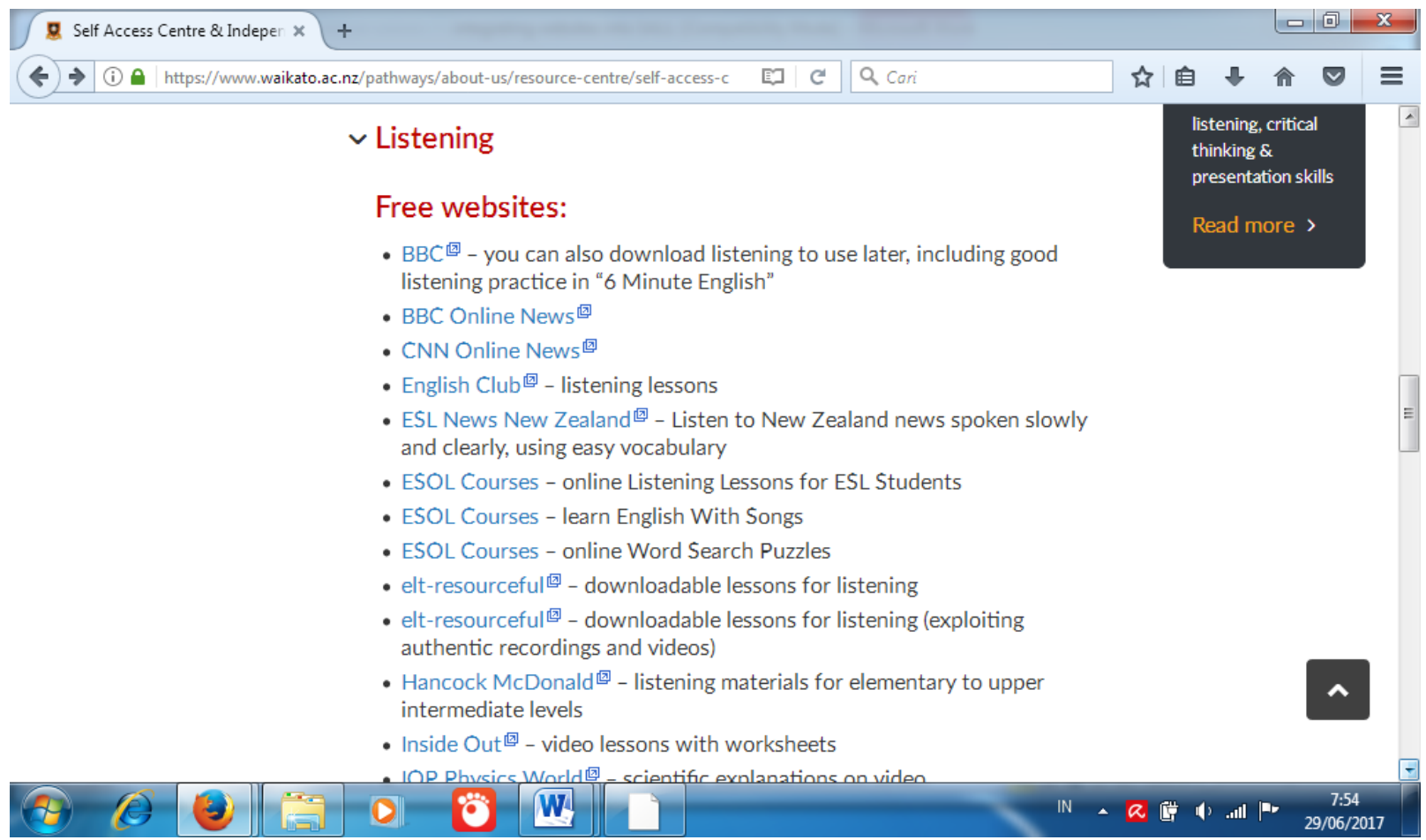

Figure 5. Listening 
Leksika Vol.13 No.1 - Feb 2019: 1 - 11

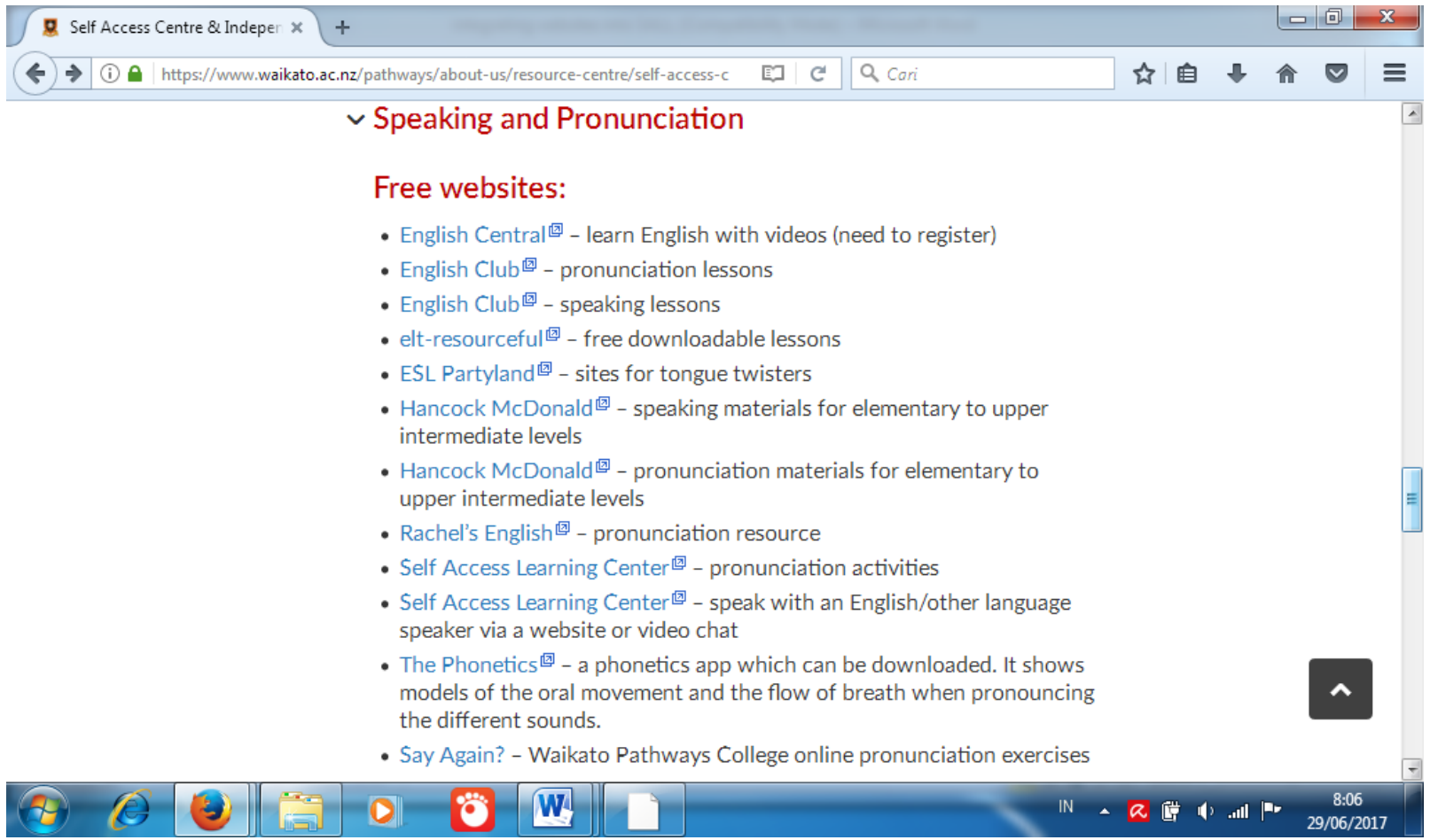

Figure 6. Speaking and Pronunciation

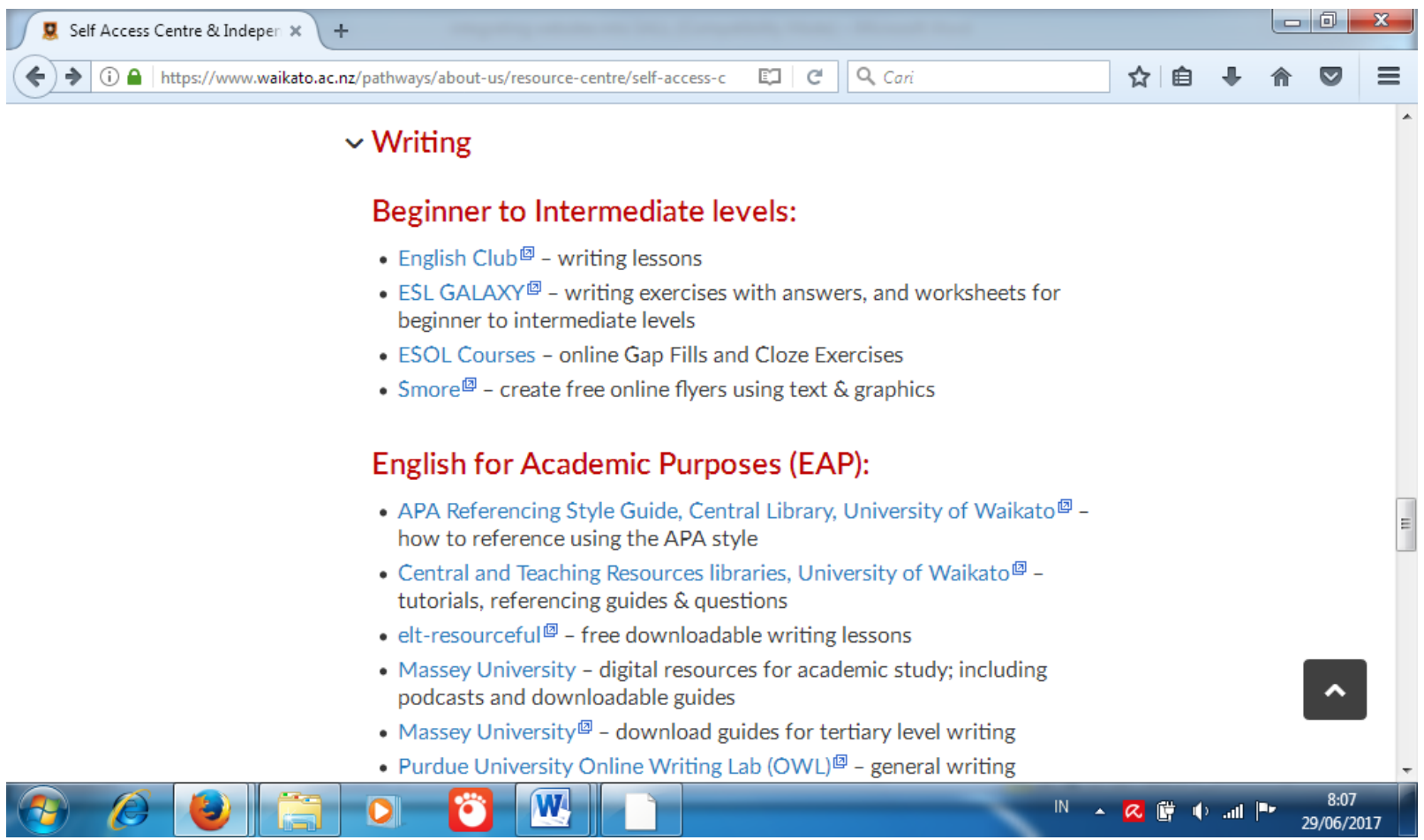

Figure 7. Writing 


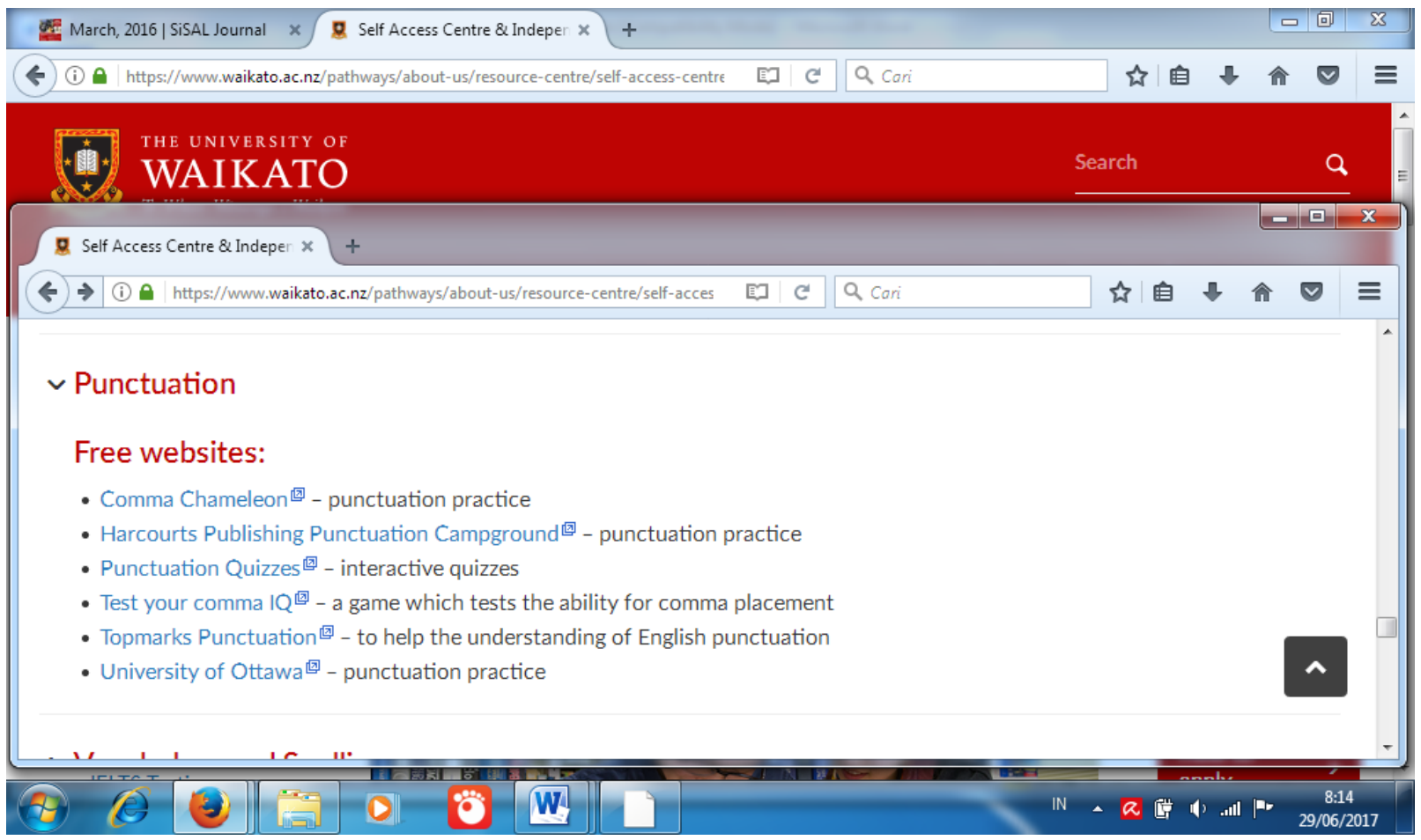

Figure 8. Punctuation

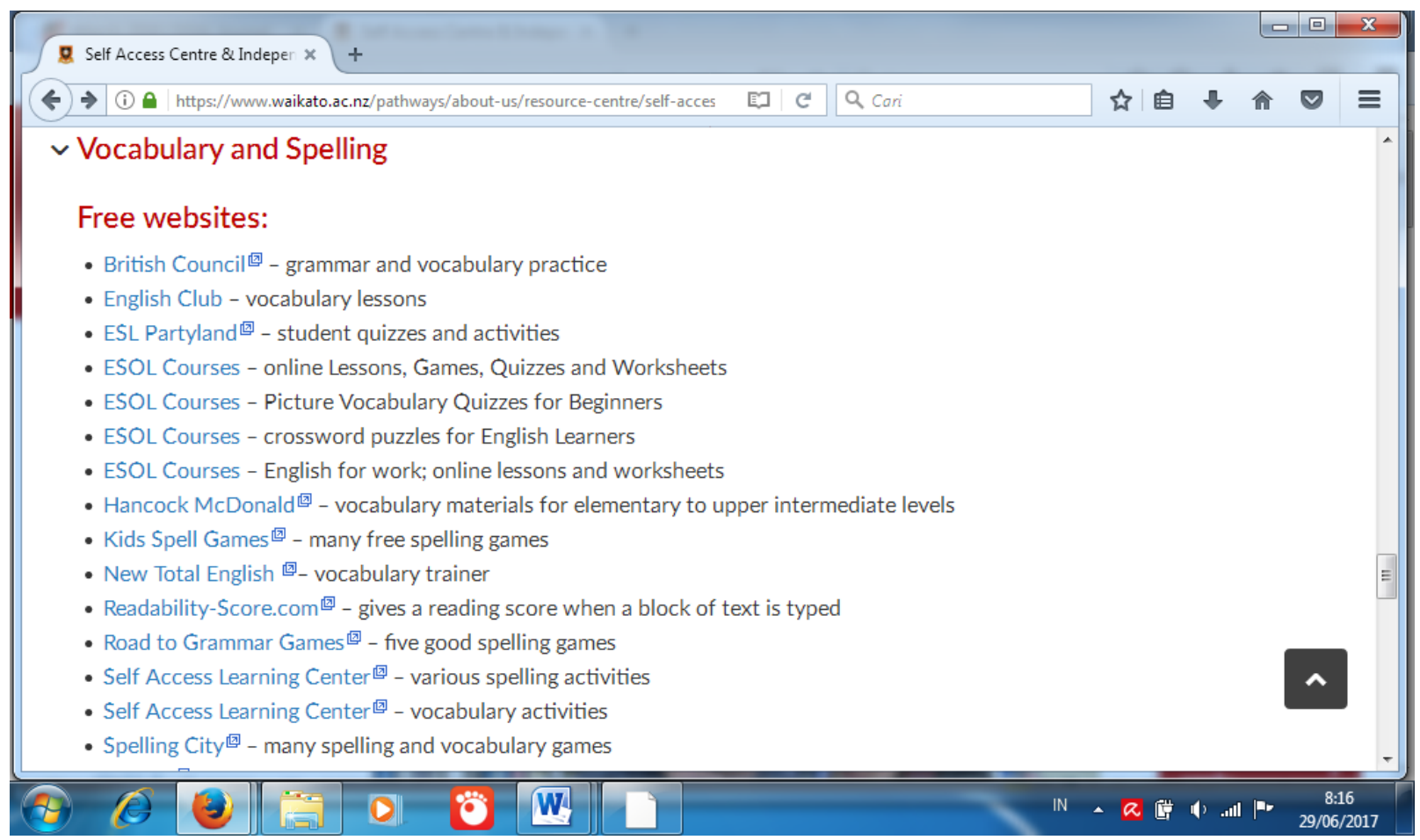

Figure 9. Vocabulary and Spelling 
Leksika Vol.13 No.1 - Feb 2019: 1 - 11

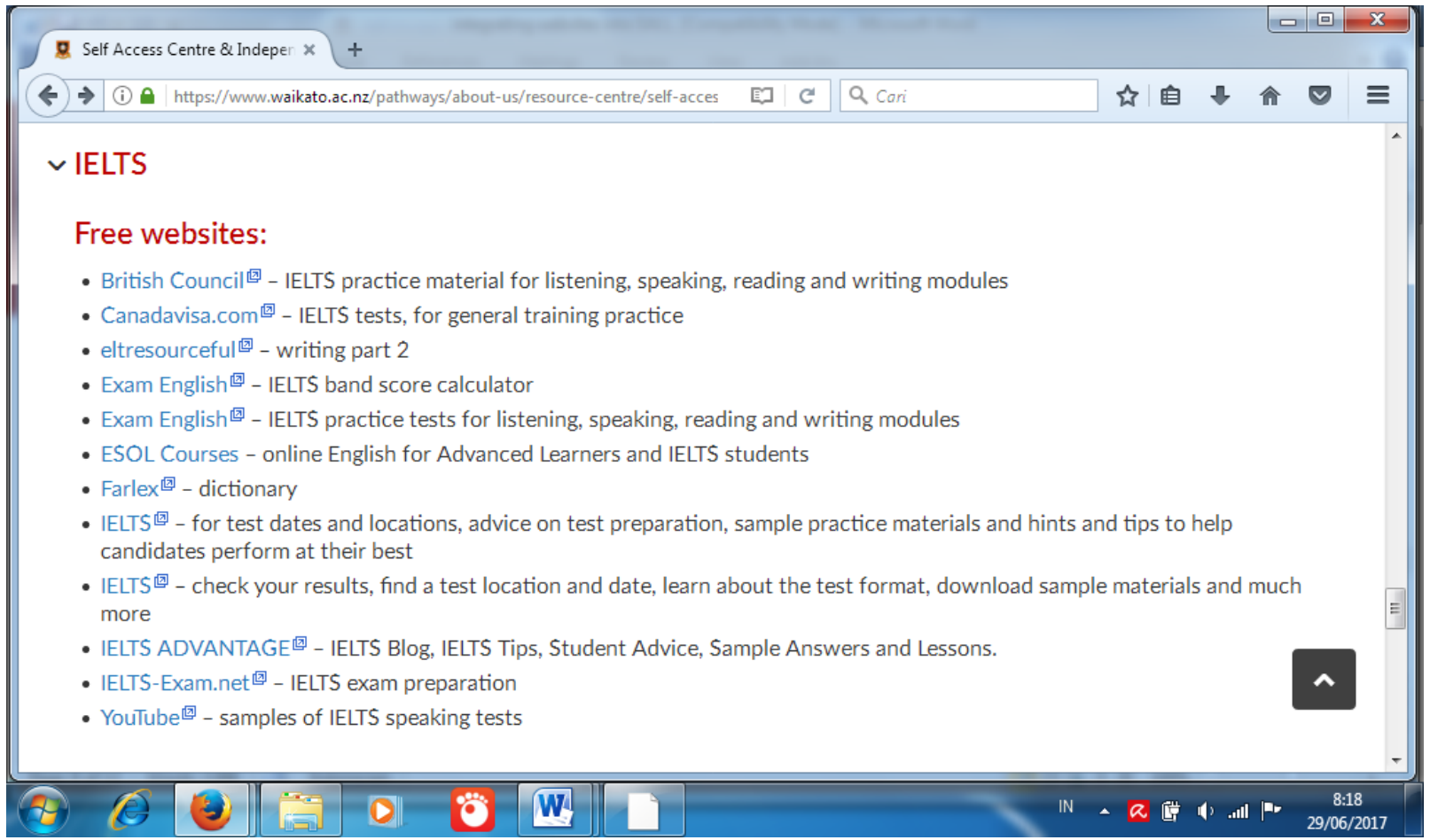

Figure 10. IELTS

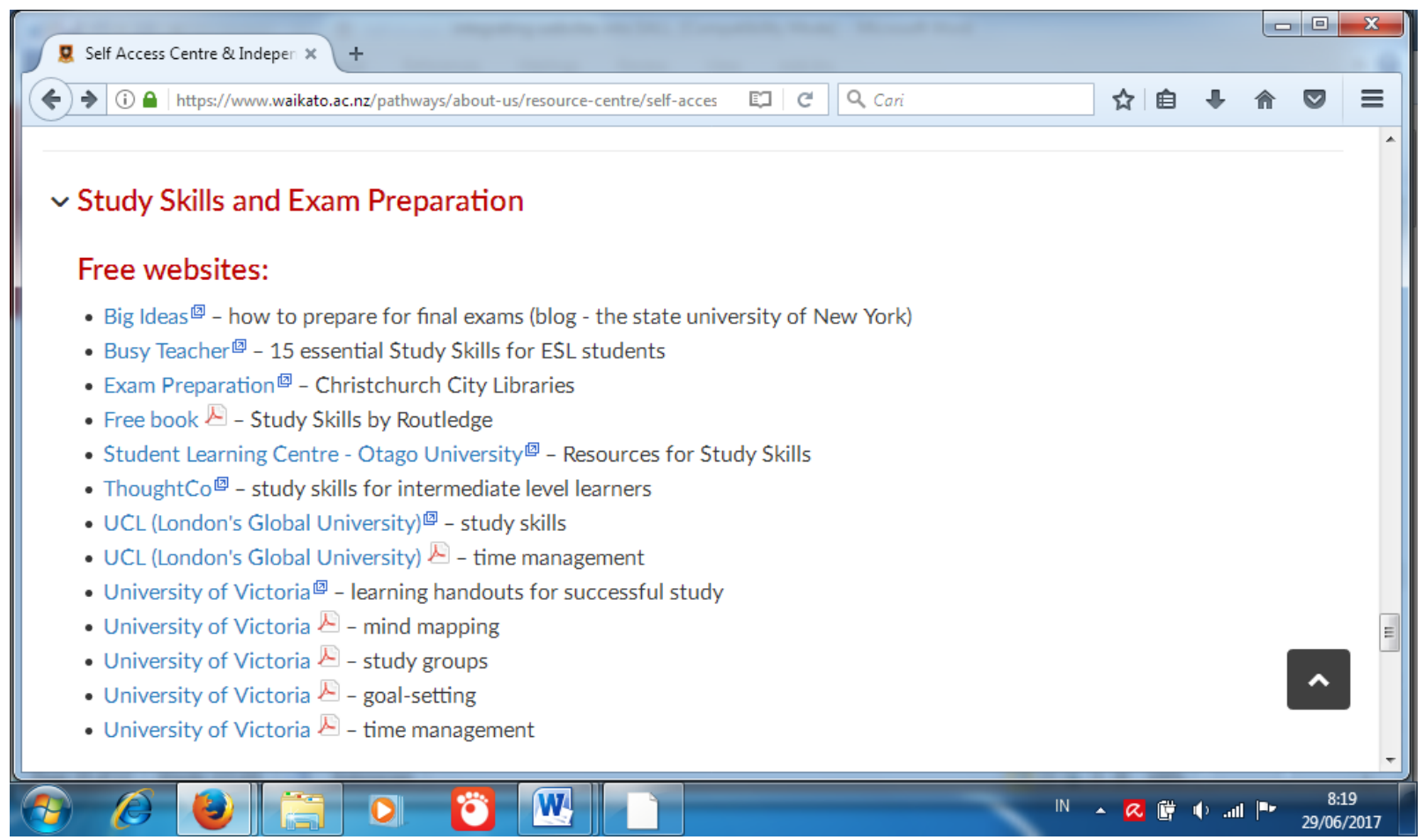

Figure 11. Study Skills and Exam Preparation

Figure 2 to Figure 11 indicate that the students or the learners have choices to select the websites provided by each of the core subjects they like, just by clicking one by one of the websites. Figure 3, for example, provides a list of websites relating to grammar materials that the learners can use to improve their grammar skills. They can do this, just by clicking each of the availabale websites. For exampale, when they click British Council grammar and vocabulary practice, the display will be in the following figure. 


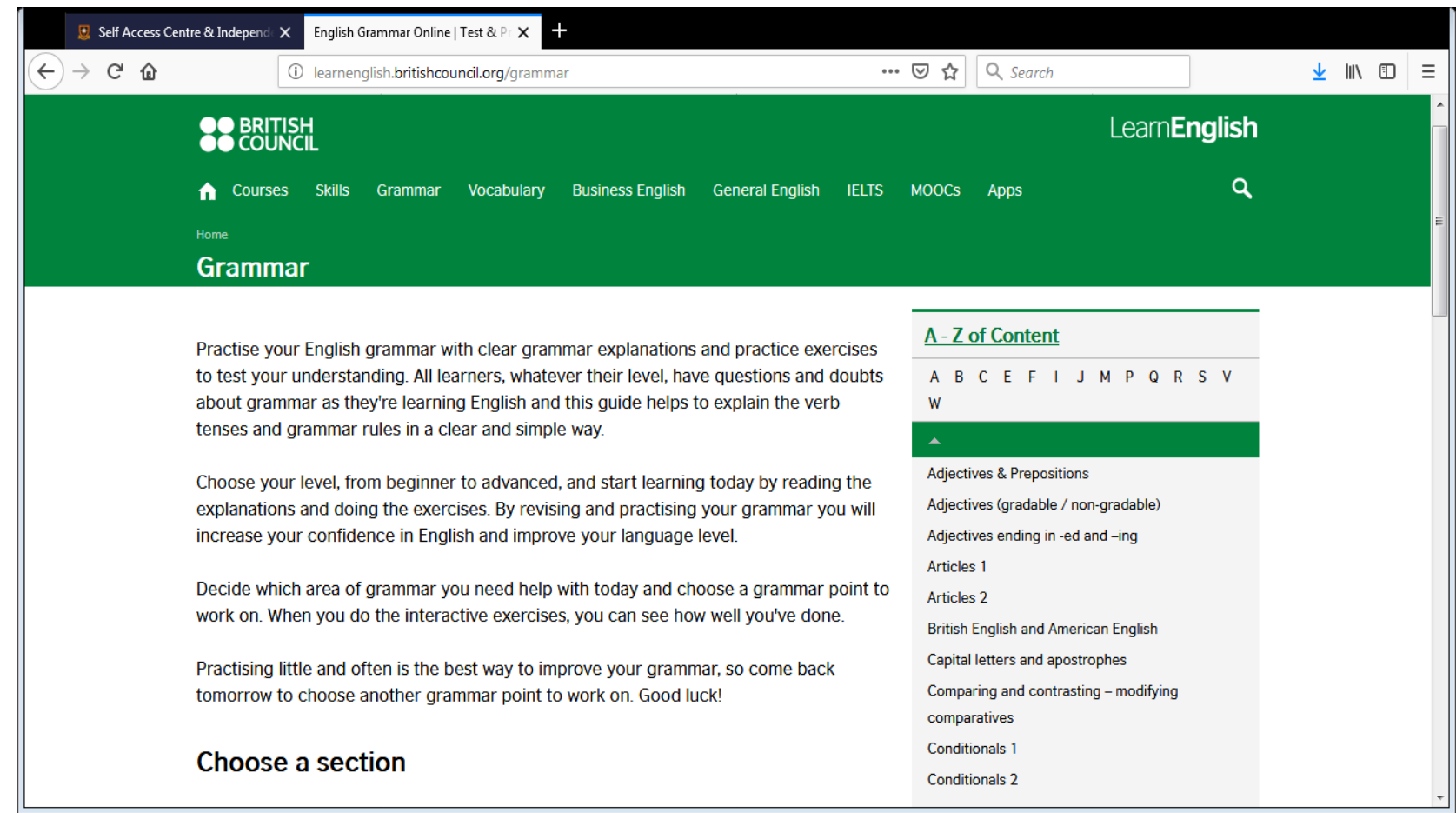

\section{Figure 12. Grammar Materials}

This figure provide a large number of topics concerning the grammar. The learners can select one of them that they like or need from the available materials on the right side from $\mathrm{A}$ to $\mathrm{Z}$. The materials in $\mathrm{A}$, for example, include Adjectives and Prepostions, Adjectives (gradable/non-gradable), Adjectives ending -ed and-ing, Article 1, and Articles 2. As well as from this side, the learners can also learn Grammar by dragging the cursor to Grammar button between Skills button and Vocabulary button and the three topics will appear in this button namely Basic grammar, Intermediate grammar, and English Grammar. From these materials the learners can access them by clicking one by one of them.
In addition, in this figure the learners cannot only access the grammar materials for their learning, they can also learn other materials through such topics relating to English learning materials as skills, vocabulary, Business English, General English, and IELTS. These materials are on the top page of the website. For example, the students of Busniess Faculty, they can drag the cursor to the button Business English and such three choices of material topics as You're Hired, Podcasts for Professionals, and Business magazine will appear on the website page. If You're Hired is clicked, the website page will be in the following figure. 


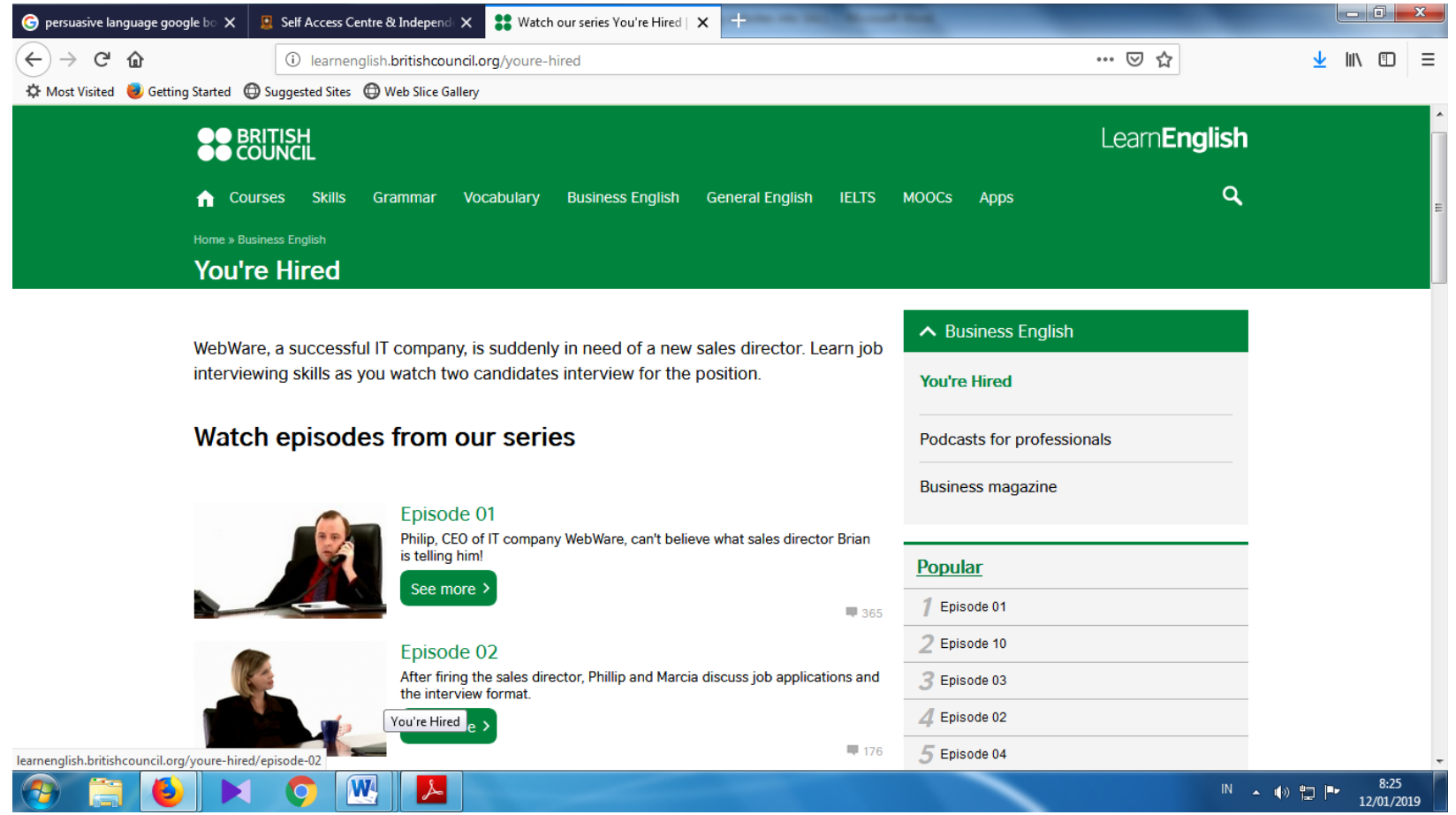

Figure 13. Busines English Materials.

The figure above indicates that there is a series of materials offered by Business English with the topic You're Hired. In this figure, the two episodes (Episode 01 and Episode 02) are of the 10 episodes. In order to have Episode 03 to Episode 10, the learners have to drag the cursor down on the page. Each episode consists of a video, two tasks (Task 1 and Task 2), and transcript that can be downloaded. With the contents of each episode, the learners can improve their listening ability by completing the two tasks while they are watching the video. To complete these tasks, they can click each task provided on the page or they can use the worksheet that they have to download first. After completing the tasks, in addition they can check their answers themselves with the answer key provided at the bottom of the worksheet. From this point, the learners themselves can evaluate their listening ability and finally they can direct themselves to decide their learning strategy..

Paying attention to SACIL set up in the University of Waikato, it is obvous enough that according to Murray and McPherson (2004) websites offer teaching materials. As a result, the EFL and ESL teachers can use them to establish SALL to facilitate their students in the framework of promoting their autonomous learning.

\section{Conclusion}

In the digital era like nowadays, the emergence of websites cannot be separated from the activities of English language teaching and learning. In other words the teachers of both English as a foreign language and English as a second language cannot ignore and avoid the websites in the framework of helping their students improve their English ability. In term of fostering their autonomous learning, the teachers or educators can use websites as a strategic way to facilitate them with a large number of materials offered by the websites provided by the Internet. Using the website-based materials they can finally set up an online Self Access Language Learning Centre (SALLC). In addition, with this centre the students can promote their autonomous learning in the framework of improving their English skills with the online materials the centrer provides. To access the materials, they must certainly use their computers connected to the Internet or their smartphones anytime and anywhere they like. However, this online SALLC can of course become in trouble because of the Internet connection. In low connection, for example, it will be difficult for the learners to access the materials. As a result, it is certainly necessary for SALLC provider to keep the Internet connection in stable condition in order that the autonomous learning process in SALLC can run well. 


\section{Notes on the Contributor}

Supardi is a teacher of English at Law faculty, the University of Jember. To promote his professionalism he has presented his papers at international conferences. In addition he has also written articles published in international journals. His interests are self access language learning, discourse study, Legal English.

\section{References}

Benson, P. (2001). Teaching and Researching Autonomy in Language Learning. New York, NY:

Longman/Pearson Education.

Cheetham, C., Elliott, M., Harper, A., \& Ito, M. (2017). Accessibility and the promotion of autonomous EFL reading. Studies in Self - Access Learning Journal, 8(1), 4-22 Retrieved from http://sisaljournal.org/archives/mar17/cheeth am_et_at.

Dofs, K., Hobbs, M. (2016). Autonomous language learning in self-access spacesMoodle in action. Studies in Self-Access Learning Journal, 7(1),72-83.

Fisher, D., Hafner, C., Young, J., 2007. Integrating independent learning: Lessons learned and implications for the classroom. In: Gardner, D. (Ed.), Learner Autonomy 10: Integration and Support. Authentik, Dublin, pp. 33-55.

Gardner, D., Miller, L., 1997. A Study of Tertiary Level Self-Access Facilities in Hong Kong. Hong Kong: City University.

Gardner, D., Miller, L., 1999. Establishing Self-Access: From Theory to Practice. Cambridge: Cambridge University Press.

Gardner, D., Miller, L. (2011). Managing self-access language learningPrinciples and practice. System, 39, 78-89.

Gibbs, G. (1995). Assessing student centred courses. Oxford, UK: Oxford Centre for Staff Learning and Development.

Gremmo, M.-J. Riley, P. (1995). Autonomy, self-direction and self access in language teaching and learning: The history of an idea. System, 23, 151-164.
Holec, H. (1981). Autonomy and foreign language learning. Oxford, UK: Pergamon.

Kir, E. Kayak, S.(2013). The evaluation of websites teaching english as a foreign language (efl). ProcediaSocial and Behavioral Science, 106, 27882795.

Littlewood, W. (1991). Curriculum Design. In R. Bowers, C. J. Brumfit (Eds.), Applied Linguistics and Language Teaching (pp. 11-22). London: Macmillan The British Council.

Lynch, A. B. \& Campos, J. L. A (2014). The Use of Technological Tools in the EFL Class. Revista de Lenguas Modernas, 20, 427-434.

McMurry, B, L., Tanner, M. W., \& Anderson, N. J. (2010). Self-Access Centers: Maximizing Learners Access to Center Resources. Studies in Self-Access Learning Journal, 1(2), 100-114.

Morrison, B., (2008). The role of the self-access centre in the tertiary language learning process. System, $36,123 \mathrm{e} 140$.

Motteram, G. (2013). The benefits of new technology in language learning. Online Magazine VOICES, 18 September. Retrieved on 13 June 2017 from HYPERLINK

https://www.britishcouncil.org/voices-magazi ne/the-benefits-new-technology-language-learni ng.

Murray, D.E. \& McPherson, P. (2004). Using the Web to support language learning. Sydney: National Centre for English Language Teaching and Research Macquarie University.

Papadima-Sophocleous, S. (2013). Self-Access Language Learning Programme: The case of the English Language Voluntary Intensive Catch-up Study. Studies in Self-Access Learning Journal, 4(2), 125-140.

Salvia, O. S. (2000). Integrating a self-access system in a language learning institutiona model for implementation. Links Letters 7, 95-109.

Sheerin, S. (1989). Self-access. Oxford: Oxford University Press.

Sheerin, S. (1991). Self-access. Language Teaching, 24 (3)143-157. 